\title{
Primordial Initiation, Yield and Yield Component Traits of Two Genotypes of Oyster Mushroom (Pleurotus spp.) as Affected by Various Rates of Lime
}

\section{Samuel C. Chukwu ( $\nabla$ chukwu.samuel@ebsu.edu.ng )}

Ebonyi State University Mushroom Center, Abakaliki.; Department of Crop Production and Landscape Management, Faculty of Agriculture and Natural Resources Management, Ebonyi State University, PMB 053, Abakaliki, Nigeria; Laboratory of Climate Smart Food Crop Production, Institute of Tropical Agriculture and Food Security, Universiti Putra Malaysia, UPM Serdang, 43400 Selangor, Malaysia.

Chidiebere A. Ibeji

Department of Crop Production and Landscape Management, Faculty of Agriculture and Natural Resources Management, Ebonyi State University, PMB 053, Abakaliki, Nigeria

\section{Chigozie Ogbu}

Department of Clinical Medicine, Ebonyi State University, Abakaliki

\section{Happiness 0. Oselebe}

Department of Crop Production and Landscape Management, Faculty of Agriculture and Natural Resources Management, Ebonyi State University, PMB 053, Abakaliki, Nigeria

\section{Emmanuel 0. Okporie}

Department of Crop Production and Landscape Management, Faculty of Agriculture and Natural Resources Management, Ebonyi State University, PMB 053, Abakaliki, Nigeria

\section{Mohd Y. Rafii}

Laboratory of Climate Smart Food Crop Production, Institute of Tropical Agriculture and Food Security, Universiti Putra Malaysia, UPM Serdang, 43400 Selangor, Malaysia. Department of Crop Science, Faculty of Agriculture, Universiti Putra Malaysia, UPM Serdang, 43400 Selangor, Malaysia

\section{Yusuff Oladosu}

Laboratory of Climate Smart Food Crop Production, Institute of Tropical Agriculture and Food Security, Universiti Putra Malaysia, UPM Serdang, 43400 Selangor, Malaysia.

\section{Research Article}

Keywords: Pin head, substrates, CaCO3, spawn inoculation, mycelia, Pleurotus ostratus

Posted Date: February 16th, 2022

DOI: https://doi.org/10.21203/rs.3.rs-1366056/v1

License: (c) (i) This work is licensed under a Creative Commons Attribution 4.0 International License. Read Full License 


\section{Abstract}

Mushrooms are fleshy fungi valued globally for their nutritional and medical benefits. The study was conducted at Ebonyi State University Mushroom Center, Abakaliki, with the aim to determine an optimum level of limestone $\left(\mathrm{CaCO}_{3}\right)$ on the genotypes for maximum growth and yield. The experiment was carried out as a split plot experiment in completely randomized design. The two genotypes were placed in the whole plot while limestone was placed in the sub-plot which consisted of five rates of $\mathrm{CaCO}_{3}(\mathrm{Og}, 5 \mathrm{~g}, 10 \mathrm{~g}, 15 \mathrm{~g}$ and $20 \mathrm{~g})$. Saw dust and rice husk substrates were used at the ratio of $60: 40$ and sterilized for six hours at $121^{\circ} \mathrm{C}$ using the steam sterilization cylinder. The media bags were off-loaded after one day and allowed to further cool for another day before inoculation. The cultured spawn were used to inoculate the media upon cooling at room temperature. Data were collected on agro-morphological parameters such as primordial initiation, stalk height, stalk diameter, number of branches, number of fruits, number of productive bags, fresh and dry weights, and subjected to analysis of variance (ANOVA). The result obtained indicated that there was a significant difference $(P<0.05)$ between the two genotypes studied in all parameters except dry weight of mushroom. Also, the various rates of $\mathrm{CaCO}_{3}$ had significant difference $(\mathrm{P}<0.05)$ in most agromorphological traits except stalk diameter, number of fruits and fresh weight. However, the interaction of whole plot (genotype) and sub-plot (lime rates) showed no significant difference $(P>0.05)$ in all parameters evaluated except the stalk diameter. Genotype I initiated more primordial compared to primordial initiation in genotype II and they differed significantly $(\mathrm{p}<0.05)$ from each other. More so, the result showed that increasing the rate of $\mathrm{CaCO}_{3}$ from $0 \mathrm{~g}$ to $5 \mathrm{~g}$ significantly increased the primordial initiation from 17 to 22 . However, further increase in lime rates above $5 \mathrm{~g}$ significantly reduced the primordial initiation from 22 to 15 . It was concluded that $5 \mathrm{~g}$ rate of limestone produced the best primordial initiation. Therefore, genotype I and $5 \mathrm{~g}$ of $\mathrm{CaCO}_{3}$ were recommended. There was also a strong relationship between the primordial initiation and most growth and yield components traits studied. There was a significant positive correlation between primordial initiation and stalk height $\left(r=0.799^{\star}\right)$, stalk diameter $\left(r=0.692^{\star}\right)$, number of mushroom branches $\left(r=0.773^{*}\right)$, number of productive bags $\left(r=0.888^{*}\right)$, number of fruits $\left(r=0.810^{\star}\right)$, fruit weight $\left(r=0.918^{*}\right)$ and dry weight $\left(r=0.916^{*}\right)$. Ideal conditions that would guarantee more primordial initiation for higher yield were recommended.

\section{Introduction}

Mushrooms (Pleurotus spp.) are valued globally for their nutritional and medicinal benefits. They contain little proportion of fats and the fatty acid fractions are mainly in the unsaturated forms like linoleic acid. Mushrooms provide excellent nutrition for ensuring proper condition of the heart, as well as the cardiovascular system ${ }^{1}$. Mushroom consumption was initially confined to some regions of the world, but technology and civilization have made it possible for consumption of mushroom to spread to various regions. Recently, mushroom consumption has gained more acceptability in different areas and utilised in preparing various dishes. There is also great export opportunities created by mushroom as different countries utilise it for various benefits. Mushroom could be consumed in various forms ranging from fresh, dried, pickled, canned, powdered, etc ${ }^{2}$. Due to the low cost of input with expected high return, more farmers and entrepreneurs have ventured into mushroom production.

Mushrooms are edible fleshy fungi, belonging to the class Basidiomycota and order Agaricomycetes. They have stem bearing a cap with gills under the cap $^{3}$. Although they are edible, some mushrooms could be wild and toxic, i.e., nonedible. Mushrooms are made up of over $90 \%$ of water and fat content is below $1 \%$. It also contains vitamin B and other elements such as selenium and copper with little quantity of sodium. Mushrooms are unique compared to other vegetables and food products because of the natural embodiment of vitamin D which could alternatively be sourced from animals and poultry. Vegetables and other food products such as milk are usually fortified with vitamin D but 
such fortification is not required in mushroom. Mushrooms are usually seen as saprophytes on wood, soil and farm lands, open fields and roadsides. The large fruiting bodies are very obvious to observe using un-aided eyes. Mushroom has various tastes, texture and flavor. Fresh mushroom contains about $80-95 \%$ moisture, $0.3-0.4 \%$ fat and $1 \%$ minerals and vitamins. Mushrooms are not destroyed by cooking, drying and freezing ${ }^{4,5}$. Edible mushrooms are recommended by the Food and Agriculture Organization (FAO) as source of protein for developing countries who feed mostly on cereal crops. Oyster mushroom, straw and ear mushrooms are the three types of mushroom currently under commercial cultivation worldwide, especially in Africa, Asia and Europe. Cultivation of mushroom could be done both under temperate and tropical climate conditions all year round. The Pleurotus species are ranked third after white button and shiitake in world production ${ }^{6}$. Mushrooms are known for bio-conversion of crop and plant residues from forest and agriculture to protein, vitamins and minerals ${ }^{5,7}$.

Large scale mushroom producers are on advantage over small scale farmers due to access to technology and capital, hence they produce large quantities of quality mushroom to meet up with the market demand ${ }^{8}$. In order to overcome the challenges facing small scale farmers, developing countries are encouraging collective action through farmers cooperative societies to improve their access to technology and credit facilities ${ }^{9,10,11}$. Forest contributes to all aspects of rural life, providing food, fodder, fuel, building materials and household items. Mushrooms are used as food and it has greater importance in human diets worldwide than ever before. There is a higher mineral content in mushroom compared to meat, fish and most vegetables ${ }^{12}$. Deforestation, bush burning and over-exploitation of forest products should be discouraged in order to reduce threat on the availability of mushroom in Nigeria. The National Mushroom Development Project introduced in 1990 for production of exotic mushrooms helped the urban unemployed youths to establish small scale mushroom farms while technologies were used for straw mushroom production ${ }^{13}$.

The growth promoting substances available in the mushroom substrates depends on the $\mathrm{pH}$ range. The growth and development of mushroom is affected by the $\mathrm{pH}$ of the substrate. Due to the fact that $\mathrm{pH}$ has effect on nutrition and morphological features of mushroom, the $\mathrm{pH}$ of the substrate should be slightly acidic to slightly basic, i.e., near neutral. According to Faryal et. al. ${ }^{14}$, the optimum $\mathrm{pH}$ range for mycelia growth and primordial initiation is 5.5-6.5. Also, Bellettini et al. ${ }^{15}$ noted that various strains of Pleurotus species required different optimum $\mathrm{pH}$ range. Despite the fact that mushroom can thrive in varied temperature conditions, Mycelium of fungi (mushroom) obtain nutrients from substrate and performs better at specific level of $\mathrm{pH}^{16}$. Lime is utilized in mushroom production to moderate the $\mathrm{pH}$ of substrate. Rapid growth of mushroom mycelia (Pleurotus sajorcaju) takes place at 6.4-7.8 $\mathrm{pH}^{17}$. Lee et al. ${ }^{18}$ on using $\mathrm{CaCO}_{3}$ as a liming material reported that the oyster mushroom performed best at $\mathrm{pH}$ near neutral and slightly basic. Asneti ${ }^{19}$ also recorded superior performance of mushroom at $2 \%$ lime when produced using wet wheat straw as medium, while Maurya et al. ${ }^{20}$ reported that the best quality spawn of oyster mushroom was produced on pearl millet and sorghum with 1:1 lime:gypsum ratio. The objective of the study was to adjust the limestone concentration of substrates in order to determine the optimum level of $\mathrm{CaCO}_{3}$ on a variety for maximum yield.

\section{Result}

\section{Agro-morphological traits}

The result in Table 1 shows that genotype I had more primordial initiation compared to variety II and they differed significantly $(P<0.05)$ from each other. Limestone levels had significant difference $(P<0.05)$ on the number of primordial initiation. Primordial initiation increased as lime rates increased from $0 \mathrm{~g}$ to $5 \mathrm{~g}$. After this rate, primordial initiation began to decrease with further increase in lime rates from $10 \mathrm{~g}$ to $20 \mathrm{~g}$. The interaction effect of the oyster 
mushroom varieties and limestone levels was not significant (Table 1). The highest number of primordial initiation was from variety 1 and $5 \mathrm{~g}$ of lime $\left(\mathrm{CaCO}_{3}\right)$ whereas the least number of primordial initiation was in variety 2 and $20 \mathrm{~g}$ concentration of lime.

The two oyster mushroom genotypes had significant difference $(P<0.05)$ on stalk height. Taller mushrooms were obtained from genotype 1 compared to genotype II. The effect of the limestone $\left(\mathrm{CaCO}_{3}\right)$ on the height of stalk was also significantly different $(\mathrm{P}<0.05)$ (Table 1$)$. The result indicated that $5 \mathrm{~g}$ of $\mathrm{CaCO}_{3}$ added to the substrates recorded the highest stalk height and this result was similar to $10 \mathrm{~g}, 5 \mathrm{~g}$ and $10 \mathrm{~g}$ of limestone $\left(\mathrm{CaCO}_{3}\right)$ rates and was significantly taller than oyster mushrooms in substrate bags with $15 \mathrm{~g}, 20 \mathrm{~g}$ and $0 \mathrm{~g}$ limestone rates.

Results showed that there was significant difference $(P<0.05)$ between the two mushroom genotypes studied. Stalk diameter of genotype I was greater than that of genotype II and they differed significantly $(P<0.05)$. Limestone levels had no significant difference $(P>0.05)$ on the stalk diameter of the oyster mushrooms. The treatment combination of the two mushroom genotypes and limestone rates interaction showed a significant effect (Table 1).

The highest number of mushroom branches was recorded in genotype 1 (Table 1$)$ which differed significantly $(P<$ 0.05) from genotype II. The levels of limestone $\left(\mathrm{CaCO}_{3}\right)$ had a significant difference $(\mathrm{P}<0.05)$ on the number of branches. As shown on Table 1, $5 \mathrm{~g}$ of limestone $\left(\mathrm{CaCO}_{3}\right)$ produced mushrooms with the highest number of branches. $10 \mathrm{~g}$ of limestone also produced similar result and the least number of branches was produced from $15 \mathrm{~g}$, $20 \mathrm{~g}$ and $0 \mathrm{~g}$. The results showed that $5 \mathrm{~g}$ limestone rate differed significantly from $20 \mathrm{~g}, 15 \mathrm{~g}, 10 \mathrm{~g}$ and $0 \mathrm{~g}(\mathrm{P}<0.05)$ while $10 \mathrm{~g}$ limestone rate differed significantly from $20 \mathrm{~g}$ and $15 \mathrm{~g}$ but the same as $0 \mathrm{~g}(\mathrm{P}<0.05)$. $0 \mathrm{~g}$ limestone rate differed significantly from $20 \mathrm{~g}$ and $15 \mathrm{~g}(\mathrm{P}<0.05)$. The treatment combination of the two genotypes and limestone levels had no significant difference (Table 1 ). Nevertheless variety 1 and $5 \mathrm{~g}$ of limestone gave the highest number of branches.

\section{Yield and yield component traits}

The result presented in Table 2 on the effect of mushroom genotypes on number of productive bags was found to have significant difference $(\mathrm{P}<0.05)$. However, genotype I recorded the highest number of productive bags which differed significantly from the number of productive bags recorded in genotype II. The effect of limestone $\left(\mathrm{CaCO}_{3}\right)$ levels as shown in (Table 2) on number of productive bag was significantly different $(P<0.05) .5 \mathrm{~g}$ and $10 \mathrm{~g}$ of limestone gave the highest number of productive bags compared to the results from $15 \mathrm{~g}, 20 \mathrm{~g}$, and $0 \mathrm{~g}$ which produced lesser number of productive bags. The least number of productive bags was found in $20 \mathrm{~g}$ limestone concentration. The results showed that $5 \mathrm{~g}$ limestone $\left(\mathrm{CaCO}_{3}\right)$ rate was significantly different from $20 \mathrm{~g}$ and $15 \mathrm{~g}$ but statistically the same as $0 \mathrm{~g}$ and $10 \mathrm{~g}$ rates $(P>0.05)$. Also, $10 \mathrm{~g}$ of $\mathrm{CaCO}_{3}$ was significantly different $(P<0.05)$ from $20 \mathrm{~g}$ and $15 \mathrm{~g}$ but significantly similar with $0 \mathrm{~g}$ and $5 \mathrm{~g}(\mathrm{P}>0.05)$. The interaction effect of the varieties of oyster mushroom and limestone levels on the number of productive bags of oyster mushroom was non-significant $(P>0.05)$. However the highest number of productive bags was obtained from genotype I and $5 \mathrm{~g}$ of limestone, while the least was obtained from genotype II and $20 \mathrm{~g}$ of limestone.

The effect of the oyster mushroom genotypes on the number of unproductive bags of oyster mushroom in (Table 2) was significant $(P<0.05)$. Genotype 1 gave the least number of unproductive bags while the highest value was recorded in genotype II and they differed significantly $(P<0.05)$. Limestone levels were significant in the resulting number of unproductive bags of oyster mushroom. Two rates; $5 \mathrm{~g}$ and $10 \mathrm{~g}$ of limestone $\left(\mathrm{CaCO}_{3}\right)$ gave the least number of unproductive bags while the greater number of unproductive bags was obtained from $15 \mathrm{~g}, 20 \mathrm{~g}$ and $0 \mathrm{~g}$ of limestone. The treatment combination of the oyster mushroom genotypes and limestone levels on unproductive bags 
of oyster mushroom was non- significant $(\mathrm{P}<0.05)$. Though, the highest number of unproductive bags was recorded in genotype II and $20 \mathrm{~g}$ of limestone while the least number was obtained from genotype 1 and $5 \mathrm{~g}$ of limestone. The results indicated that $20 \mathrm{~g}$ level of limestone differed significantly from $10 \mathrm{~g}, 5 \mathrm{~g}$ and $0 \mathrm{~g}$ but the same as $15 \mathrm{~g}$. Also, $15 \mathrm{~g}$ limestone level differed significantly from $10 \mathrm{~g}$ and $5 \mathrm{~g}$ levels of $\mathrm{CaCO}_{3}$ but the same as $0 \mathrm{~g}$ limestone level $(P>0.05)$.

Results revealed that mushroom genotypes had a significant effect on the number of fruits. The highest number (13.19) of fruits was recorded in genotype I while genotype II produced the least (5.59), and they differed significantly $(P<0.05)$ from each other. There was no significant difference in limestone rates, as well as interaction effects (Table 2). The two varieties of oyster mushroom had significant effect on the fresh weight of the mushroom (Table 2). The highest fresh weight was recorded in genotype I and the least in genotype II and they differed significantly $(P<0.05)$. The effect of limestone levels $\left(\mathrm{CaCO}_{3}\right)$ on the fresh weight of mushroom had no significant difference. Nonsignificant difference was also observed in the interaction results (Table 2)

As presented in Table 2, there was significant difference $(P<0.05)$ between the two oyster mushroom genotypes on dry weight. The highest dry weight value was recorded in genotype I while the lowest was recorded in genotype II and they differed significantly $(\mathrm{P}<0.05)$. The effect of limestone $\left(\mathrm{CaCO}_{3}\right)$ rates on the dry weight also had significant difference $(P<0.05)$. However, $5 \mathrm{~g}$ and $10 \mathrm{~g}$ limestone concentration produced the highest dry weight. Results showed that $5 \mathrm{~g}$ limestone rate differed significantly from all other limestone rates studied $(0 \mathrm{~g}, 15 \mathrm{~g}, 10 \mathrm{~g}$, and $20 \mathrm{~g})$. Also, $0 \mathrm{~g}$ limestone rate differed significantly from $20 \mathrm{~g}$ lime rate but the same as $15 \mathrm{~g}$. There was no significant difference in the interaction effects (Table 2)

\section{Relationship among the traits studied}

The result in Table 3 shows that there was a significant positive correlation between primordial initiation and stalk height $\left(r=0.799^{*}\right)$, stalk diameter $\left(r=0.692^{*}\right)$, number of mushroom branches $\left(r=0.773^{*}\right)$, number of productive bags $\left(r=0.888^{*}\right)$, number of fruits $\left(r=0.810^{*}\right)$, fruit weight $\left(r=0.918^{*}\right)$ and dry weight $\left(r=0.916^{*}\right)$. However, primordial initiation correlated negatively with number of unproductive bags $\left(r=-0.897^{*}\right)$. This result indicates that increasing the primordial initiation would significantly increase other traits studied except number of unproductive bags. Positive and significant correlations were also observed between stalk height and stalk diameter $\left(r=0.948^{*}\right)$, number of fruits $\left(r=0.897^{*}\right)$ and fruit weight $\left(r=0.937^{*}\right)$. Stalk diameter also had positive and significant correlation with number of fruits $\left(r=0.927^{*}\right)$ and fruit weight $\left(r=0.902^{*}\right)$. Number of mushroom branches correlated positive and significant with number of productive bags $\left(r=0.840^{*}\right)$ and dry weight $(r=0.919 *)$. Number of productive bags also had positive and significant correlation with fruit weight and dry weight with $r=0.794^{*}$ and $0.907 *$, respectively. Unproductive bags had negative correlations with all other traits indicating that reduction in number of unproductive bags could lead to increase in other traits studied, and vice-versa. In addition, number of fruits correlated positively and significantly with fruit weight $\left(r=0.927^{\star}\right)$ while fruit weight had positive and significant relationship with dry weight $\left(r=0.716^{\star}\right)($ Table 3). 
Table 3

Correlation coefficients between primordial initiation and other agro-morphological traits studied

\section{Pearson Correlation Coefficients, $\mathbf{N}=10$}

Prob $>|r|$ under $\mathrm{HO}:$ Rho $=0$

\begin{tabular}{|c|c|c|c|c|c|c|c|c|c|}
\hline & $\mathrm{PI}$ & $\mathrm{SH}$ & SD & NB & NPB & NUPB & NF & FW & DW \\
\hline PI & 1.00000 & & & & & & & & \\
\hline \multirow[t]{2}{*}{ SH } & 0.79941 & 1.00000 & & & & & & & \\
\hline & 0.0055 & & & & & & & & \\
\hline \multirow[t]{2}{*}{ SD } & 0.69241 & 0.94787 & 1.00000 & & & & & & \\
\hline & 0.0265 & $<.0001$ & & & & & & & \\
\hline \multirow[t]{2}{*}{ NB } & 0.77298 & 0.33455 & 0.15651 & 1.00000 & & & & & \\
\hline & 0.0087 & 0.3447 & 0.6659 & & & & & & \\
\hline \multirow[t]{2}{*}{ NPB } & 0.88750 & 0.59703 & 0.52238 & 0.84036 & 1.00000 & & & & \\
\hline & 0.0006 & 0.0684 & 0.1214 & 0.0023 & & & & & \\
\hline \multirow[t]{2}{*}{ NUPB } & -0.89729 & -0.67377 & -0.61598 & -0.78168 & -0.98922 & 1.00000 & & & \\
\hline & 0.0004 & 0.0327 & 0.0579 & 0.0076 & $<.0001$ & & & & \\
\hline \multirow[t]{2}{*}{ NF } & 0.81033 & 0.89706 & 0.92685 & 0.35865 & 0.61753 & -0.70058 & 1.00000 & & \\
\hline & 0.0045 & 0.0004 & 0.0001 & 0.3088 & 0.0571 & 0.0240 & & & \\
\hline \multirow[t]{2}{*}{ FW } & 0.91760 & 0.93650 & 0.90221 & 0.50727 & 0.79391 & -0.85468 & 0.92688 & 1.00000 & \\
\hline & 0.0002 & $<.0001$ & 0.0004 & 0.1345 & 0.0061 & 0.0016 & 0.0001 & & \\
\hline \multirow[t]{2}{*}{ DW } & 0.91559 & 0.53649 & 0.41552 & 0.91915 & 0.90702 & -0.87220 & 0.60133 & 0.71635 & 1.00000 \\
\hline & 0.0002 & 0.1099 & 0.2324 & 0.0002 & 0.0003 & 0.0010 & 0.0659 & 0.0198 & \\
\hline
\end{tabular}

\section{Discussion}

Primordial initiation is one of the main parts of emergence of mushrooms. Result obtained from this study showed that primordial initiation was faster in treatments having genotype 1 and $5 \mathrm{~g}$ of lime. It was deduced from the result that primordial initiation increased from 18.67 to 26.33 as lime rate increased from $0 \mathrm{~g}$ to $5 \mathrm{~g}$, respectively. The primordial initiation declined as lime rate was further increased to $10 \mathrm{~g}, 15 \mathrm{~g}$ and $20 \mathrm{~g}$ with pin head setting of 24.33 , 21.33 and 17.67, respectively. Primordial initiation is the growth of tiny mushroom fruiting bodies with a size of about $0.01 \mathrm{~mm}$. They start developing soon after completion of spawn running. Adjusting the $\mathrm{pH}$ by varying the rate of lime added to the substrate could directly affect the primordial initiation. Khan et al. ${ }^{21}$ found that various rates of lime had significant difference on number of days taken for primordial initiation. The result revealed that $0 \%$ lime and $2 \%$ lime both facilitated primordial initiation three days after completing spawn running while further increase of lime to $4 \%$ 
and $6 \%$ significantly delayed primordial initiation to five and six days after spawn running, respectively. The study conducted by Hlerema et al. ${ }^{22}$ on mushroom production using maize industry's waste materials showed that spawn running lasted 17-20 days while primordial initiation started one week after the completion of spawn running. This result corresponds with the findings made by Khan et al. ${ }^{21}$ and Tirkey et al. ${ }^{23}$ on number of pinheads (primordial initiation). The result showed that there was increase in primordial initiation from $0 \%(28.3)$ to $2 \%$ (30.8) with a significant reduction in primordial initiation as lime rate increase from $4 \%(20.4)$ to $6 \%$ (11.8). Also, Khan et al. ${ }^{21}$ and Bhattacharjya et al. ${ }^{24}$ studied oyster mushroom production on various lingo cellulosic substrates and observed that primordial initiation took 7-8 days after spawn running while formation of sporocarps occurred after 10-12 days after mycelia growth.

The mushroom branches are also known as the fruiting bodies or the sporophore. Good environmental conditions of the media such as high relative humidity and low temperature enhance the production of healthy mushroom fruiting bodies. Most species of oyster mushroom require relative humidity above $85 \%$ and temperature between $15-250 \mathrm{C}$ for maximum growth and yield ${ }^{25,26}$. The result of this present study agrees with Khan et al. ${ }^{21}$ who found that $6 \%$ lime with $\mathrm{pH} 8.7$ produced minimum number of mushroom fruiting bodies (7.4) followed by $4 \%$ lime (16.4), $0 \%$ lime (24.2) and $2 \%$ lime (26.8) at $\mathrm{pH} 8.2,7.2$ and 7.8 , respectively. The least lime rate applied, i.e., $2 \%$ produced highest number of fruiting bodies (26.8) which differed significantly from the number of fruiting bodies recorded in $0 \%, 4 \%$ and $6 \%$. The result is also in agreement with Mondal et al. ${ }^{27}$ who worked on various substrate compositions for oyster mushroom cultivation. Spawn running was under a steady temperature of $25^{\circ} \mathrm{C}$ while fruiting was at a temperature range of $17-$ 220C. They also found that spawn running took two to three weeks upon inoculation while primordial initiation started after 6-7 weeks after spawn running completed. Fruiting bodies developed after three to six days of primordial initiation and took 27-34 days after inoculation of spawn. They also reported that $100 \%$ sawdust produced the highest yield of $646.9 \mathrm{~g}$, production efficiency of $64.69 \%$ and number of fruiting bodies put at $22.11^{28}$.

Result shows that increasing the lime dosage beyond $5 \mathrm{~g}$ led to a decline in yield of the oyster mushroom (Fig. 2). Genotype I also produced higher yield compared to genotype II. The result obtained on yield of mushroom from this study agrees with that of Bedford and Rousseau. ${ }^{29}$ (2013) who reported that mushroom yield increased from $53.08 \mathrm{~g}$ to $56.32 \mathrm{~g}$ with increase in lime from $0-2 \%$, respectively. However, the yield of mushroom significantly decreased to $32.17 \mathrm{~g}-23.37 \mathrm{~g}$ with further increase in lime rate to $4 \%-6 \%$, respectively. Substrates composed with $2 \%$ lime and that of control ( $0 \%$ lime) had same significance level at pH 7.8 and 7.2 with mushroom fresh weight of $56.32 \mathrm{~g}$ and $53.08 \mathrm{~g}$, respectively but differed significantly from substrates composed with $4 \%$ lime and $6 \%$ lime with $\mathrm{pH}$ of 8.2 and 8.7, respectively. Other researchers have also reported similar results. Liaqat et al. ${ }^{30}$ worked on response of various means of preparing compost and limestone concentration on the yield and yield components of Pleurotus sajorcaju and reported that wet wheat straw and $2 \%$ of $\mathrm{CaCO}_{3}$ produced the fastest spawn running (23 days), early primordial initiation (48 days), highest number of flushes (six) and the highest mushroom yield ( $295 \mathrm{~g} / 1.5 \mathrm{~kg}$ substrate). Significant positive correlation between primordial initiation and other growth and yield attributes observed in this study corresponds with the findings made by Chukwu et al. ${ }^{31}$. Selecting for high primordial initiation would lead to increase in yield of the oyster mushroom.

\section{Conclusion}

The treatment combination comprising genotype I and 5grams of lime showed the best results in primordial initiation and other growth and yield component traits of the oyster mushroom which included stalk height, stalk diameter and number of mushroom branches, number of fruits, fresh weight, dry weight and productive bags. Although lime was necessary in adjusting the $\mathrm{pH}$ of the substrates, maximum concentration of $5 \mathrm{~g}$ was ideal for maximum yield. Higher 
concentrations above $5 \mathrm{~g}$ are discouraged, as such led to decline in yield of the oyster mushroom. It can also be concluded that there was a strong relationship between the primordial initiation and other growth and yield components traits studied. Ideal conditions that would guarantee the initiation of more primordial (pin heads) for higher yield are recommended.

\section{Materials And Method}

This experiment was carried out at the Ebonyi State University Mushroom Centre, Abakaliki, from February to November 2021 under a homogeneous environment with high relative humidity. The Center lies at the latitude $06^{0}$ $40^{\prime} \mathrm{N}$ and longitude $08^{\circ} 65^{\prime} \mathrm{E}$ and altitude of $91.44 \mathrm{~m}$ above sea level. This area is characterized by a bimodal pattern of rainfall (April-July) and (September- November) with a short dry spell in August normally called the "August Break", The total rainfall ranges from $1700 \mathrm{~mm}-2000 \mathrm{~mm}^{32}$.

\section{Experimental design}

The study was conducted as a split plot experiment laid out in completely randomized design (CRD). The whole plot comprised two spawn genotypes (GI and GII) while the sub-plots consists of five rates of $\mathrm{CaCO}_{3}(0 \mathrm{~g}, 5 \mathrm{~g}, 10 \mathrm{~g}, 15 \mathrm{~g}$, $20 \mathrm{~g}$ ) and the 10 treatment combinations were replicated three times. The arrangement of treatments (experiment design) is as shown in Figure 1.

\section{Isolation and Tissue Culture}

Samples were isolated from the desired fruiting bodies (basidiocarps) of mushroom from which pure cultures were obtained. The uncontaminated tissues were obtained by pulling apart the cap of the mushroom. The isolated samples were cut into tiny pieces with the aid of sterilile fine-tip tweezers and surface-sterilized using Sodium Hypochlorite solution and washed off in distilled water before transferring to the potato dextrose agar (PDA) plate. Sub-culturing was done under aseptic conditions using the laminar flow hood to avoid any form of contamination. New cultures were re-labeled and kept as pure/mother cultures. The pure cultures were stored at $4^{\circ} \mathrm{C}\left(39^{\circ} \mathrm{F}\right)^{33}$.

\section{Mother Spawn Preparation}

The millet seeds were soaked for about 12 hours. The seeds were drained and transferred into $1000 \mathrm{ml}$ conical flask. The seeds were sterilized inside the flask using autoclave in order to ensure there was no contamination. The flasks were half-filled with the millet seeds to create enough space for mycelia growth. The seeds were shook vigorously soon after it was brought out of the autoclave in order to mix the seeds on top part of the flask, which tend to be drier compared to the seeds at the bottom of the flask where moisture drops while cooling. Preventing agglutination of the seeds into a single big mass could be another reason for shaking thoroughly ${ }^{34}$.

\section{Media Preparation and Sterilization}

After the individual collection of substrates, they were weighed according to the ratio $80: 20 \mathrm{~kg}$ of sawdust and rice husk, respectively. The substrate compositions were mixed with $\mathrm{CaCO}_{3}(\mathrm{Lime})$ at five different levels as described earlier in the experiment design. All the media was sterilized using heat from steam at $121^{\circ} \mathrm{C}$ for 8 hours using the steam sterilization cylinder. Then, all media was left to cool for 24 hours before off-loading from the cylinder and further allowed to cool for another 24 hours at room temperature before inoculation ${ }^{35}$.

\section{Inoculation, Spawn Running and Fruiting}


After sterilization, the inoculation room was fumigated. The media was carried to the inoculation room. At the inoculation room, each of the media was inoculated with $10 \mathrm{~g}$ of spawn under aseptic condition. Proper distribution of the spawn on top of the media was ensured. The substrates were transferred inside the incubation room with ambient temperature maintained and relative humidity of $80-85 \%$ for five weeks. Watering can was used to sprinkle water on the media, twice daily at the early hours of the day and in the evening. At the end of the colonization period, the bags were taken to the fruiting room and rearranged horizontally. After the mycelium is fully colonized and the media are completely white, the upper part of the bags was unfolded to induce fruiting for the first flush. The pin head formation could be seen on the surface of the media after two to three days. The pinheads of the mushrooms grow into full-size within three to five days interval after pinhead formation ${ }^{34,36}$.

\section{Data Collection and Analysis}

Data were collected and properly recorded on primordial initiation, stalk height and diameter, number of mushroom branches, number of productive and unproductive bags, number of fruits, fresh weight and dry weight of mushroom. Data collected were subjected to statistical analysis of variance (ANOVA) for split plot experiment in completely randomized design (CRD) using SAS software version 9.4. Separation of treatment means for significant effect and correlation analysis were also done using the SAS software ${ }^{37}$.

\section{Declarations}

Funding: This study was supported by Ebonyi State University Management.

Conflicts of Interest: "The authors declare no conflict of interest."

\section{References}

1. Calorie Bee. Rajan Singh Jolly, Nutritional Facts and Uses of Edible Mushrooms Accessed 10/6/2021.

2. Gusman, J. K., Lin, C. Y., \& Shih, Y. C. (2014). The optimum submerged culture condition of the culinary-medicinal white jelly mushroom (Tremellomycetes) and its antioxidant properties. International journal of medicinal mushrooms, 16(3).

3. Stanley HO, Umolo EA, Stanley CN, 2011. Cultivation of oyster mushroom (Pleurotus pulmonarius) on amended corncob substrate. Agriculture and biology journal of north America. 2(8)1239-1243.

4. Nair, N.G. and K.Y. Cho. 1982. Oyster mushroom new "gouerment" mushroom will be cheaper to grow. Agri. Gazette of New South Wales 93(2): 29-30.

5. Belitz, H-D., Werner Grosch, and Peter Schieberle. "Vegetables and vegetable products." In Food Chemistry, pp. 772-805. Springer, Berlin, Heidelberg, 2004.

6. Győrfi, J., \& Hajdu, C. S. (2007). Casing-material experiments with Pleurotus eryngii. International Journal of Horticultural Science, 13(2), 33-36.

7. Thakur, M. P. "Advances in mushroom production: key to food, nutritional and employment security: A review." Indian Phytopathology 73, no. 3 (2020): 377-395.

8. Rana, S. S., and Pankaj Chopra. "Integrated farming system." Department of Agronomy, College of Agriculture, CSK Himachal Pradesh Krishi Vishvavidyalaya: Palampur, India (2013). 
9. Ahenkan A, Boon E. Commercialization of non-timber forest products in Ghana: Processing, packaging and marketing. Journal of Food, Agriculture and Environment. 2010 Apr 1;8(2):962-9.

10. Sawyerr, L.C. (2010). Sclerotium formation on sawdust compost by Pleurotus tuberregium, a medicinal Ghanaian mushroom.

11. Sultana R, Hossain MI, Saifullah AR, Chakraborty R. Influence of Substrate pH and Watering Frequency on the Growth of Oyster Mushroom. Int. J. Plant. Biol. Res. 2018;6(4).

12. Zhang L, Sun X. Changes in physical, chemical, and microbiological properties during the two-stage cocomposting of green waste with spent mushroom compost and biochar. Bioresource technology. $2014 \mathrm{Nov}$ 1;171:274-84.

13. Raman J, Lee SK, Im JH, Oh MJ, Oh YL, Jang KY. Current prospects of mushroom production and industrial growth in India. Journal of Mushroom. 2018;16(4):239-49.

14. Faryal R, Sultan A, Tahir F, Ahmed S, Hameed A. Biosorption of lead by indigenous fungal strains. Pakistan Journal of Botany. 2007 Apr 1;39(2):615.

15. Bellettini MB, Fiorda FA, Maieves HA, Teixeira GL, Ávila S, Hornung PS, Júnior AM, Ribani RH. Factors affecting mushroom Pleurotus spp. Saudi Journal of Biological Sciences. 2019 May 1;26(4):633 - $46 .$.

16. Tesfaw A, Tadesse A, Kiros G. Optimization of oyster (Pleurotus ostreatus) mushroom cultivation using locally available substrates and materials in Debre Berhan, Ethiopia. Journal of Applied Biology and Biotechnology. 2015 Feb 27;3(1):0-2.

17. Ghareeb, B. A. "Impact of Different Levels of Calcium Carbonate (CaCO3) on the Growth and yield of Oyster Mushroom (Pleurotus spp.)." Accessed on 2/6/2021

18. Lee $\mathrm{CH}$, Lee DK, Ali MA, Kim PJ. Effects of oyster shell on soil chemical and biological properties and cabbage productivity as a liming materials. Waste Management. 2008 Dec 1;28(12):2702-8.

19. Asneti T. Effect of different substrate supplements on oyster mushroom (Pleurotus spp.) production. Food Science and Technology. 2013;1(3):44-51.

20. Maurya AK, John V, Srivastava DK, Sobita Simon S, Pan H. Effect of media and substrates for spawn production of dhingri mushroom (Pleurotus ostreatus). Journal of Natural Resource and Development. 2019;14(2):88-92.

21. Khan MW, Ali MA, Khan NA, Khan MA, Rehman A, Javed NJ. Effect of different levels of lime and pH on mycelial growth and production efficiency of oyster mushroom (Pleurotus spp.). Pak. J. Bot. 2013 Feb 1;45(1):297-302.

22. Hlerema IN, Eiasu BK, Koch SH. Pineapple (Ananas comusus) plant material as supplement for maize residuebased oyster mushroom substrate and reduction of cadmium soil contamination. HortScience. $2017 \mathrm{Apr}$ 1;52(4):667 - 71.

23. Tirkey VJ, Simon S, Lal AA. Efficacy of different substrates on the growth, yield and nutritional composition of oyster mushroom-Pleurotus florida (Mont.) Singer. Journal of Pharmacognosy and Phytochemistry. 2017;6(4):1097-100.

24. Bhattacharjya DK, Paul RK, Miah MN, Ahmed KU. Effect of different saw dust substrates on the growth and yield of oyster mushroom (Pleurotus ostreatus). IOSR Journal of Agriculture and Veterinary Science. 2014;7(2):38-46.

25. Nongthombam JE, Kumar AD, Ladli BG, Madhushekhar MA, Patidar SU. A review on study of growth and cultivation of oyster mushroom. Plant Cell Biotechnology and Molecular Biology. 2021 Feb 11;22(5\&6):55-65.

26. Islam MT, Zakaria Z, Hamidin N, Ishak MA. Indoor Cultivation Model of Humidifying and Ventilation Systems for Grey Oyster Mushroom (Pleurotus pulmonarius). Indian Journal of Science and Technology. 2017 Nov 1;10(41).

27. Mondal SR, Rehana J, Noman MS, Adhikary SK. Comparative study on growth and yield performance of oyster mushroom (Pleurotus florida) on different substrates. Journal of the Bangladesh Agricultural University. 
2010;8(2):213-20.

28. Shah ZA, Ashraf M, Ishtiaq M. Comparative study on cultivation and yield performance of oyster mushroom (Pleurotus ostreatus) on different substrates (wheat straw, leaves, saw dust). Pakistan Journal of Nutrition. 2004;3(3):158-60.

29. Bedford $M$, Rousseau X. Recent findings regarding calcium and phytase in poultry nutrition. Animal Production Science. 2017 Jul 21;57(11):2311-6.

30. Liaqat R, Shafiq M, Naeem MS, Ali MA, Ali S, Sardar H. Growth and yield performance of oyster mushroom on different substrates. Mycopath. 2014 Dec 26;12(1).

31. Chukwu SC, Ekwu LG, Onyishi GC, Okporie EO, Obi IU. Correlation between agronomic and chemical characteristics of maize (Zea mays L.) genotypes after two years of mass selection. International Journal of Science and Research. 2013;4(8):1708-12.

32. Chidiebere-Mark N, Ohajianya D, Obasi P, Onyeagocha S. Profitability of rice production in different production systems in Ebonyi State, Nigeria. Open Agriculture. 2019 Jan 1;4(1):237-46.

33. Ubi BE. Crop Production Biotechnology. Universal Academic services, Nigeria. 2013:47-62.

34. Ahmed A. Efficacy of different concentrations of seed extract of Carica papaya against Clinical Isolates of Entamoeba histolytica (Doctoral dissertation, East West University). Accessed 5/6/2021

35. Witherel CE. Biomaterial-Mediated Control over Macrophage Behavior for Tissue Regeneration. Drexel University; 2019.

36. Pathmashini L, Arulnandhy V, Wijeratnam RW. Cultivation of oyster mushroom (Pleurotus ostreatus) on sawdust. Ceylon Journal of Science. 2008;37(2):177-82.

37. Eslinger J. The SAS Programmer's PROC REPORT Handbook: Basic to Advanced Reporting Techniques. Sas Institute; 2016 Mar 23.

\section{Tables 1 And 2}

Tables 1 and 2 are available in the supplementary files section.

\section{Figures}




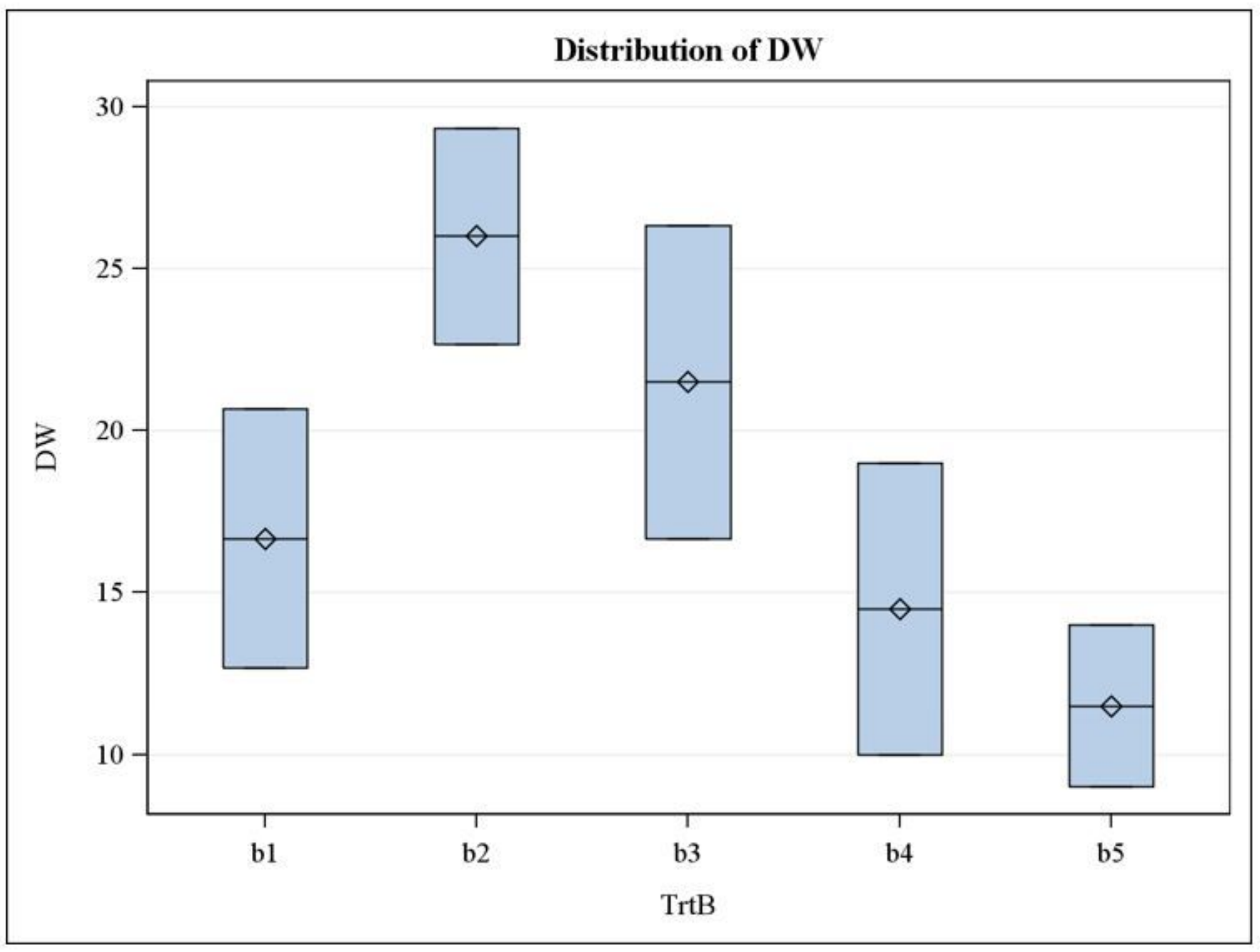

Figure 1

The split plot experiment design 


\section{GI-ABA}

\begin{tabular}{|c|c|}
\hline $10 \mathrm{~g} \mathrm{CaCO}_{3}$ & $0 \mathrm{~g} \mathrm{CaCO}_{3}$ \\
\hline $15 \mathrm{~g} \mathrm{CaCO}_{3}$ & $10 \mathrm{~g} \mathrm{CaCO}_{3}$ \\
\hline $0 \mathrm{~g} \mathrm{CaCO}_{3}$ & $20 \mathrm{~g} \mathrm{CaCO}_{3}$ \\
\hline $20 \mathrm{~g} \mathrm{CaCO}_{3}$ & $5 \mathrm{~g} \mathrm{CaCO}_{3}$ \\
\hline & \\
\hline & \\
\hline $\mathrm{g} \mathrm{CaCO}_{3}$ & $15 \mathrm{~g} \mathrm{CaCO}_{3}$ \\
\hline
\end{tabular}

Figure 2

Effects of Limestone levels on dry weight of mushroom

\section{Supplementary Files}

This is a list of supplementary files associated with this preprint. Click to download.

- Table1.docx

- Table2.docx 